\title{
A Tax Shelter for Students: Yale's Tuition Postponement Option
}

During the 1971-72 academic year, Yale University introduced a new student loan program, the Tuition Postponement Option (TPO). ${ }^{1}$ Under the plan, students borrow from the university, with repayments made at a percentage of their future incomes for up to thirty-five years. Depending on his income level during the repayment period, a student may repay more or less than he would under a conventional loan taken at commercial interest rates.

Similar programs, hereafter referred to as contingent repayment plans, have been previously proposed, usually with the federal govern. ment making loans directly to students on a national scale.2 The

1. Approval of the plan was announced on February 5, 1971. Yale Daily News, Feb. 5, 1971, at 1, col. 1 (extra ed.). N.Y. Times, Feb. 6, 1971, at 26, col. 1. For a detalled description of the plan as initially announced, see Yale University, Yale Tuition post. ponement Option, Feb. 6, 197 I (Background Detail for Release Morning Papers). 'This statement is reprinted in full in Yale Daily News, supra, at 2, col. 1, and in Hearings on the Education Amendments of 1971 Before the Subcommittee on Education of thic Senate Committee on Labor and Public Welfare, 92d Cong., 1st Scss., pt. 5, at 3014 (1971) [hereinafter cited as 1971 Education Hearings].

2. The first proposal for such loans was apparently made by Milton Friedmall. He proposed a government loan program with payments to be a fixed percentage of income above a given base. Friedman, The Role of Government in Education, in Ecovomes AND THE Punlic INTERest 123, 140 (R. Solo ed. 1955). A slightly revised version of this paper appears in M. Friedsan, Capitalisit and Freedom 105 (1962).

A major boost for the concept came from a 1967 Office of Education study which recommended that the federal government set up an Educational Opportunity Batnk to make student loans on similar principles. Repayments would be a fixed percentage of income, with no borrower paying more than under a conventional federal student loan. Panel on Educational Innovation, Educational Oprontunity Bank 1.2, 11.1\% (1967) [hereinafter cited as ZACHARIAs RePORT]. The report is reprinted in full in Hearings on the Higher Education Amendments of 1970 before the Subcommiltec on Education of the Senate Comm. on Labor and Public Welfare, 91st Cong., 2d Sess., pt. 1, at 315.37 (1970) [hereinafter cited as 1970 Education Hearings].

In December 1968 the Carnegie Commission on Higher Education recommended a similar federal loan plan and called for further study of its details. The plan (cxcept for administration) would be self-sustaining, with interest based on federal borrowing costs. Carnegie Commission on Higher Education, Quality and Equaltry: New Levels OF FEDERAL RESPONSIBILITY FOR HIGHER Education 27-29 (1968). However, the following month, an HEW Report to the President recommended against such a loan plan largely, because a heavy federal subsidy would have been required in the "almost guarantecd" event that borrowers would be predominantly students who would have low future earnings. U.S. Dep'T OF HEW, Toward a Long-Range Plan for Federal Financial SUPPORT FOR HIGHER EDUCATION 24 \& n.3, 65 (1969), reprinted in 1970 Education Hearings, supra, pt. 1, at 357-437 [hercinafter cited as RIvLin REPORT] [page citations are to 1970 Education Hearings]. Instead, the Report proposed fixed-interest loans with no federal subsidy, and a repayment schedule (payments possibly increasing over time) fixed in advance. A very limited cancellation feature for borrowers with low incomes would allow forgiveness of up to ten per cent of the payments due in any given year. Id. at 398.99, 433-34. The Carnegie Commission then retreated from its carlier position and recommended a loan plan similar to that proposed in the RivLiN Relortr combincel with grants to needy students. Carnegie Commission on Hicier Education, Qunlity ANd EQUality: Revised Recommendations-New Leveis of Federal. Resionsidility' yon Higher Education 68-69 (1970). The relevant section of this report is printed in 1970 Education Hearings, supra, pt. 3, at 1618-23. 
major stated purpose of such a national deferred tuition plan has been to widen access to higher education for students from low-income families by increasing their willingness to borrow. 3

Present methods of promoting equality of educational opportunity have not been effective. ${ }^{4}$ Educational institutions are in financial crisis ${ }^{\sigma}$ and cannot increase conventional forms of aid to meet rapidly increasing costs of attendance. ${ }^{\circ}$ The federal response thus far has also been

In 1970 a detailed proposal for a plan very similar to TPO was made by Robert Carlsson. Payments would be a fixed percentage of income above a base level (TPO differs in not having a base level), with a maximum payment for borrowers with ver; high incomes. The percentage would be set so that the plan would break eren. Howerer, the break-even point would be based upon a subsidized interest rate, so borrowers vith high incomes would not be significantly worse off than under a commercial loant. Carlsson, A Federal Program of Student Loans, 29 A.4. J. OF EcoN. \& Sociolocr 263 (1970).

It was against this background that the Yale TPO Plan was announced. For a comprehensive bibliography of books and articles on deferred tuition, sec Yale University Tuition Postponement Option Office, Contingent Repayment Loans: Bibliography; Nov. 19, 1971 (mimeo.). For other plans currently being implemented, see note 81 infra.

3. See, e.g., Zacharias Rerort, supra note 2, at 1; CirNeGIE Commission on Hicile? Education, Quality aNd Equality: New Levels of Federat, Restonsibitity For Hicilen. Education 28 (1968). Dr. Rivlin believes equality of opportunity should be the goal of any federal aid policy. 1970 Education Hearings, supra note 2, pt. 1, at 347.

4. Only 20 per cent of the 1967 high school graduates from families with incomes under $\$ 3000$ entered college. For those with family incomes in the range $\$ 10,000-15,000$, 60 per cent entered college. For family incomes over $\$ 15,000,95$ per cent entered college. 1970 Education Hearings, supra note 2, pt. 1, at 540.

Even after adjustments for ability, the differenees remain large. See generally Berls, Higher Education Opportunity and Achievement in the United States, in Jolst Economic Committee, The Economics and Financing of Higher Education in thie Unitre States: A Compendum of Papers, 91st Cong., lst Sess. 145 (Comm. Print 1969) [hereinafter cited as EcoNomics Compendum]. For example, of 1965 high school graduates in the second ability quintile 84 per cent of those in the top sociocconomic quartile, as opposed to only 36 per cent of those in the bottom socioeconomic quartile, entered college within 5 years. Id. at 147,150 . If all students of any given ability quintile entered college in the same proportion as do those students with the same ability but from the top socioeconomic quartile, an additional 600,000 students from each high school graduating class would eventually enter college. Id. at 151, 196.

5. See E. Chert, The New Depression in Higner Entaition (1971). In this study for the Carnegie Commission on Higher Education and the Ford Foundation, Cheit studied forty-one representative public and private institutions of higher edueation. Extrapolating his data to a national scale, the Carnegic Commission staff concluded that 39 per cent of all institutions, representing 22 per cent of all students are "not in financial trouble"; 42 per cent of all institutions, representing $5:$ per cent of all stldents, are "headed for financial trouble"; and 19 per cent of all institutions representing 24 per cent of all students, are "in financial trouble." Id. at $x$.

See also Jellema, The Red and the Black, in Hearings on the Higher Education Amendments of 1971 Before the Special Subcomm. on Education of the House Commiltec on Education and Labor, 92d Cong., Ist Sess., pt. I, at 151 (1971) [hereinafter cited as 1971 Amendment Hearings].

6. For the decade ending in 1967-68, the average annual increase in tuition and required fees was 7.5 per cent for private institutions and 5.8 per cent for public ones. Cherr, supra note 5, at 13 . In 1971-72, tuition, room and board at public institutions averaged \$1248; for all private institutions, \$2722; for private universities alone, \$3168. 1971 Education Hearings, supra note 1 , pt. 1 , at 609 . The poor financial condition of institutions is due in part to the large and increasing expenditures on student financial aid. 1971 Amendment Hearings, supra note 5 , pt. 1, at 147. Many administrators at private institutions fear that their schools will soon be populated exclusively by the very rich and the very poor on full scholarships. See, e.g., id. at 148; CiterT, supro note 5, at 13; N.Y. Times, Apr. 20, 1972, at 49, col. 6. 
inadequate. ${ }^{7}$ In fact, a major reason for federal reluctance to institute a contingent repayment plan has been an unwillingness to absorb large losses in the event that only students with low future incomes borrow under the program. ${ }^{8}$

A contingent repayment plan, however, need not be subsidized."

7. Roughly one million of the $2 \%$ million students from familics with inconcs under $\$ 10,000$ are not receiving federal education assistance. 1971 Amendment Hearings, supra note 5, pt. 1, at 269 (testimony of Dr. Muirhead). Lack of finances is the domintant reason for the failure to attend college, according to the Office of Education. Id. at 250. Recognition of the general problem is what led the Nixon administration to press for the enactment of the Education Amendments of 1972, Pub. L. No. 92.318 (Junc 23, 1972), See generally 1971 Amendment Hearings, supra note 5 . The Act authorizes an cstimated $\$ 800$ million to $\$ 1$ billion annually for institutional grants, an estimated $\$ 850$ million annually for grants to needy students, and $\$ 40$ million for colleges in grave finautitil difficulty. Chronicle of Higher Education, May 22, 1972, at 2, col. 1. Actual spending is likely to be considerably less, however. For example, institutional aid is likely to total less than $\$ 100,000,000$. N.Y. Times, Mar. 2, 1972, at 45, col. 7.

Federal loan programs-are the major concern of this Note. The most significant of these is the Federal Guaranteed Loan Program, 20 U.S.C. $\$ \$ 1071-87$ (1970) which wis amended by the Education Amendments of 1972, Pub. L. No. 92.318 (Junc 23, 1972). The government insures or reinsures the principal and interest on loans mate by states or institutions to individual students. Students can borrow, ustally from a local bank, up to $\$ 2500$ per year to an undergraduate maximum of $\$ 7500$. The loans nutst be repaid within ten years, and payments each year must total $\$ 360$. The studeut cat1 be charged no more than seven per cent interest on the unpaid principal balance, but the government will pay the lender an additional amount of up to three per cent. The loatus are further subsidized for students from families with adjusted income levels below $\$ 15,000$, and students from families with higher incomes, who obtain certificates of nced from their colleges. These students are charged no interest until they begin repayments following graduation, the government paying the lender the full intercst cost for the interim period.

Over $\$ 1$ billion in guaranteed loans were made in the first eight months of fiscal 1972. Cole, Personal Finance: Students' Defaults, N.Y. Times, Mar. 30, 1972, at 55, col. 2.

The Education Amendments of 1972, Pub. L. No. 92-318, $\$ 137$ (June 23, 1972), also establishes direct federal loans to students to replace the similar National Defense Edu. cation Act (NDEA) loans. Institutions receive funds from the federal goverument to make loans to needy students, the institution itself being required to put up onc-ninth of the federal contribution. Undergraduates are eligible for up to $\$ 5000$ in such loans, Repayments begin following graduation, and require a minimum annual payment of $\$ 360$ and a maximum term of ten years. No interest is charged until repayments begin, and then the interest is only three per cent. Portions of the loans are forgiven for borrowers who later enter certain teaching and military positions.

A total of $\$ 369$ million of NDEA loans were available in 1970-71. 1971 Education Hearings, supra note 1 , pt. 1 , at 588 .

Other provisions of the Education Amendments of 1972, Pub. L. No. 92.318 (Junc 23, 1972), though not directly relevant for purposes of this Note, are clearly of major significance. For example, $\$ 131$ of the Act authorizes Basic Educational Opportunity Grants to each college student of up to $\$ 1400$, less the expected family contribution, but no more than 60 per cent of his total cducation cost for the year.

8. This was the reason the RIvLIN REIORT opposed any plan in which total payments would significantly depend on income. See note 2 supra.

9. The presence of a subsidy makes it possible to allow borrowers who will have below average incomes to pay less, without requiring borrowers who will have above average incomes to pay more than they would under a conventional loan. $\Lambda$ partitlly subsidized plan would use a repayment rate set so that borrowers with high incomes would pay penalties less on the whole than the cost to the lender of forgiving payments by borrowers with low incomes. The same result could occur inadvertently if the av. erage income of borrowers was below the predicted incomes from which the repayment rate was derived.

Any plan designed to "break even" at an interest rate below the market rate is, in 
The Yale system is designed to be self-supporting. The repayment rate is set at a level that compels high-income borrowers to pay a penalty equal to any payments forgiven to low-income borrowers. ${ }^{10}$ Borrowers having high incomes will therefore pay more than they would have under a conventional loan. Of the several plans that are now in effect or will shortly be initiated, ${ }^{11}$ the Yale Plan provides the only test of whether a self-supporting contingent repayment plan can succeed despite this penalty on those who will have high incomes. ${ }^{12}$

The Internal Revenue Service has recently ruled that all payments made by Yale TPO borrowers in excess of the principal amount borrowed, including the penalty paid for having a high income, will be deductible as interest for federal income tax purposes. ${ }^{13}$ The effect of this Ruling is to make TPO more attractive to those anticipating a high income, as the tax saving from this deduction will offset a substantial portion of the high-income penalty.14

Following a description of the TPO Plan and the Revenue Ruling, this Note will argue that the penalty should not be deductible as interest. Moreover, viewing this interest deduction as a subsidy to TPO borrowers, ${ }^{15}$ there is no reason to believe that it is any more efficient than alternative TPO subsidies in promoting equal educational opportunity. Finally, it will be suggested that the grant of this

fact, subsidized, since the public or private lender incurs an opportunity cast by lending money under the plan. Of the proposals in note 2 supra, the only self-supporting plans were the original Friedman proposal and the later modified 1968 Camegie Commission proposal.

10. The terms "high-income" and "low-income" refer to borrowers whose future incomes are, respectively, above and below average relative to all borrowers under the plan.

11. Duke University instituted a contingent repayment plan at the same time as Yale; Harvard University is instituting a plan this year. A New York State plan begins in 1973-74. See note 81 infra.

12. The Yale plan is admittedly experimental. Yale Daily News, supra note 1 , at 1 , col. 1. N.Y. Times, supra note 1 , at 26 , col. 1.

Some 50 to 60 per cent of the undergraduates were initially expected to borrow under the plan. Id. Actual figures were somewhat lower.

Of Yale undergraduates, 25 per cent borrowed under the plan during 1971.72 , the figures ranging from 35 per cent of the freshmen to 19 per cent of the seniors. The maximum allowed sum of $\$ 800$ was taken by 69 per cent of the borrowers, 58 per cent of the freshmen to 84 per cent of the seniors. Women borrowed at a slightly lower rate than men. Yale University, 1971-72 Participation Analysis: Yale College, Mar. 22, 1972 (mimeo.).

13. Rev. Rul. 72-2, 1972 INT. Rev. BuLc. No. 2, at 11.

14. See note 83 infra.

15. See generally Surrey, Tax Incentives versus Direct Government Expenditures, 83 HARv. L. REv. 705 (1970).

The interest deduction on the principal amount of the original loan is a subsidy for loans rather than for education. The present discussion concerns only the cxira de. duction granted to high-income borrowers, which is more directly a subsidy for cdu. cation. In theory the principle of contingent repayment borrowing could be used for any large-scale borrowing based on future income, but none aside from education loans has yet been proposed. 
questionable interest deduction may in fact hinder desirable experimentation in identifying the most effective use of government funds in support of a contingent repayment system.

\section{The TPO Contract}

Under the Yale TPO, the university enters into a separate contract ${ }^{10}$ with each student borrower in which the borrower agrees to pay to the university, for each $\$ 100$ borrowed, ${ }^{17}$ an amount equal to $.04 \mathrm{pcr}$ cent of his or her ${ }^{18}$ adjusted gross income ${ }^{10}$ (subject to a minimum payment) ${ }^{20}$ for a period of up to thirty-five years. ${ }^{21}$ The repayment period normally begins the year following graduation. ${ }^{29}$

All borrowers whose repayment periods begin in any given year form a Repayment Group. ${ }^{23}$ An account called the Group Termination Account is maintained by the university for each Repayment

16. The document described is the Yale University $1971-72$ Tuition l'ostponcment Option Plan: Yale College, July 1, 1971 [hercinafter cited as Contract]. Explanations in the text may go beyond the literal wording of the section(s) cited. Gradulte and professional students are covered under separate documents with identical scction 11tul. bering and only necessary minor changes.

17. The 1970-7I Yale College combined fee for undergraduate tuition, roon, and board was $\$ 3900$. Undergraduates could borrow under $\mathrm{TPO}$, in any year, a maximum of $\$ 300$ plus the amount by which fees in that year cxceeded those in 1970.71. Given a projected $\$ 300$ annual increase in fees ( $\$ 500$ the first year), a freshman cntering in the fall of 1971 could borrow a maximum of approximately $\$ 5000$ during his four yeats. Yale Daily News, supra note 1, at 2, col. 1.

In any year a student elects to borrow under the plan, he must borrow at least $\$ 900$; and he may borrow any amount (in increments of $\$ 50$ ) up to the maximum for that year. Unused borrowing in one year does not increase the maximum an individual maty borrow in subsequent years. Id. and Contract $\$ 4.01$. A further limitation is that the amount borrowed must be used to defray educational expenses. Contract $\$ 4.01$. Gradı* ate students can borrow as much as $\$ 2400$ per year. Yale University, Gencral Bulletln and Weekly Calendar, Mar. 10, 1972, at 2, col. 1.

18. The plan is completely sex-neutral. A borrower who files an individual inconc tax return pays the .04 per cent rate solely on his or her own reported inconic, re. gardless of marital status. If a borrower marries and files a joint return, however, he or she pays on the greater of (1) half the joint income, or (2) the income that would have been reported on an individual return. Contract $\$ 6.01(\mathrm{~b})$.

19. The income tax definition is used. INT. REv. CoDE of $1954 \$ 62$. If a borrower is not obligated to file a tax return, the repayment amount is computed as if one were filed. Furthermore, if the Code is amended so that the amended definition of adjusted gross income is "substantially different" from the 1971 definition, the 1971 definition applies. Contract $\$ \$ 6.01(a)(1) \cdot(3)$.

20. See p. 1397 infra.

21. Contract $\$ \S 6.02(\mathrm{~b}), 7.01,7.03$. The .04 per cent figure has no relation to an interest rate; rather it determines the amount in dollars that is paid in a given year. The rate comes to $\$ 4$ per $\$ 1000$ of income per $\$ 1000$ borrowed. For example, a borrower of $\$ 3500$ who in a given year has an income of $\$ 20,000$ will owe $\$ 280$ (\$4 times 3.5 times 20) the following year.

22. The payment term begins in the year following the first calendar year at the end of which the borrower is 21 years old and is no longer a candidate for any academic degree. Thus any degree program at any institution delays the start of the repayment period. However, Yale may nevertheless require payments to begin if the borrower has been a candidate for ten or more academic years. Contract $\$ 7.02$.

23. Contract $\$ 8.01(a)$. 
Group. At formation of the Group, its balance is the total amount borrowed by all members of the Group, plus accumulated interest at a Contract Interest Rate (CIR). ${ }^{24}$ Each year during the repayment period, the balance is increased by the amount of interest at the CIR and decreased by the total amount paid by members of the Group.25

Group Termination occurs if the balance of the Group Termination Account reaches zero within thirty-five years. At that time, all borrowers in the Repayment Group who have repaid the principal amount borrowed are relieved of all further obligation.." But each borrower has a minimum personal obligation to repay the principal amount borrowed, without interest; this obligation survives Group Termination. ${ }^{2 T}$ A required minimum annual payment of $\$ 2.90$ per $\$ 100$ borrowed $^{28}$ ensures that the principal will be repaid within the thirty-five year period. In no event does a borrower pay for more than thirtyfive years. ${ }^{29}$

There are two circumstances in which a borrower may stop making payments before Group Termination. The first is the borrower's death. Any principal still outstanding is paid by a life insurance policy carried by the university on the lives of all borrowers. ${ }^{30}$ The other circumstance which ends all obligation is Early Termination. This occurs when the borrower has himself repaid at the CIR, 150 per cent of the principal borrowed. ${ }^{31}$ Early Termination may be achieved through the normal course of payments by borrowers with high incomes, $^{32}$ or by any borrower through making a "buy-out" payment at any time. ${ }^{33}$

The CIR itself is not a fixed rate, but rather one calculated periodically by the university to reflect its cost of financing and admin-

24. See pp. 1397-98.

25. Contract $\$ 10.02$.

26. Id. $\$ \S 11.03-04$.

27. If less than the principal amount has been paid at Group Termination, the remainder must be paid in equal annual installments ending in the thirty-fifth jear. Interest at the CIR which was in effect for the year of Group Termination must be paid on the balance, but only from the time of Group Termination. Id. \$11.0J.

28. Id. $\$ 6.02(\mathrm{a})$. A borrower with an income below $\$ 7250$ thus pays the minimum amount rather than the percentage rate.

29. Id. \$ 7.03 .

30. Id. \$ 13.02. Insurance proceeds are treated as payments by the borrower and when paid reduce the balance in the Group Termination Account. Id. $\$$ 10.02, 13.0J.

31. An Early Termination Account is maintained for each borrower, with an initial balance of 150 per cent of the amount borrowed. The Account balance increases at the CIR, and is reduced by payments made by the borrover. The balance is thus at all times the amount necessary to pay off 150 per cent of the amount borrowed at the CIR. Early Termination occurs when the balance becomes zero. Contract $\$ \$ 10.03,11.02$.

32. Borrowers with incomes of at least 50 per cent above the arerage for their Group will reach this maximum level by making the required annual pajments. See note 53 infra.

33. Contract $\$ 6.06$. See note 31 supra. 
istering the plan. The university borrows (by means of short-term commercial notes) an amount equal to the outstanding debt of all student borrowers (including prior years' interest). ${ }^{34}$ Semi-annually the university determines the average interest rate it is paying on these notes and adds a service charge (not to exceed 1 per cent) to cover the cost of administering the plan. ${ }^{35}$ The resulting $\mathrm{CIR}^{\mathrm{ad}}$ is used to compute the new balance in the Group Termination account and the amount each borrower must pay to achieve Early Termination.

\section{The Revenue Ruling}

When Yale first announced the TPO Plan, it was noted that all loan repayments beyond the principal amount would probably be deductible as interest for federal income tax purposes. ${ }^{37}$ The university subsequently requested a ruling from the Internal Revenue Service (IRS) and received a letter confirming this tax treatment. ${ }^{38}$ Shortly thereafter the letter was formally published by the IRS as a Revenue Ruling. ${ }^{39}$

The Ruling has five major sections. It holds, first, that participants will not realize taxable income from the initial tuition deferral, since "the participant has an unconditional and legally enforceable obligation to make certain payments to the university." 40 Second, it accepts the proposed allocation of a borrower's payments to his principal until paid and the remainder to interest. ${ }^{41}$ Third, the Ruling holds that payments allocated to principal or to life insurance premiums are not deductible. ${ }^{42}$

34. Tobin \& Pugash, The Economics of the Tuition Postponement Option 1, Feb. 10, 1971 (mimeo.).

35. Contract $\$ \S 9.02-03$.

36. Estimates are made by the University using an expected average CIR of seven per cent. See note 83 infra.

37. Yale Daily News, supra notc 1 , at 2 , col. 5 .

38. The letter was written Aug. 2, 1971. Yale University, THE Relokr of dill PRESIDENT: 1970-71, at 12 n.11 (1971).

39. Rev. Rul. 72-2, supra note 13. The ruling precisely describes the Yale plan. $\Lambda$ s to the effect of such rulings a Revenue Ruling is an "official interpretation" of thic tax code published for "information and guidance" of interested persons. Rev. 1'roc. 72.1, 1972 INT. Rev. Bull. No. 1, $\$ 2.01$, at 4 . Published Rulings do not have the force of Regulations but "provide precedents to be used in the disposition of other cases, and may be cited and relied upon for that purpose." Id. $\$ 6.01(4)$.

40. Rev. Rul. 72-2, supra note 13 , at 11 .

41. Id. The usual allocation of each payment on a loan is first to accrucd interest, with any remainder reducing the principal amount outstanding. However, parties to a loan transaction are free to allocate payments between principal and interest in any way they desire. The precedents are reviewed in Rev. Rul. 57, 1963.1 Cus. Butl. 103, which holds that a small loan company may allocate all payments to principal until it is entirely repaid.

42. Rev. Rul. 72-2, supra note 13, at 11-12. 
This Note questions only the fourth and fifth decisions in the Ruling. The fourth holds that, "the amounts paid by each participant in excess of the amount allocated to principal and insurance premiums is interest and deductible under the provisions of section 163(a) of the Code." 43 The Ruling cites precedent to the effect that interest is simply "the amount one has contracted to pay for the use of borrowed money, and as the compensation paid for the use or forbearnnce of money," ${ }^{44}$ and that interest need not be calculated as a percentage of principal, so long as it is "a sum definitely ascertainable." 45 No distinction is drawn between payments made before the participant has repaid the amount of his own loan at the CIR and those made after that time, which are described above as the high-income "penalty." 4

Finally, the Ruling holds that a participant who repays less than the amount of his own loan at the CIR does not receive taxable income in the amount of his deficiency at Group Termination. The rationale given is that,

each participant has an individual obligation to pay the university his deferred amount. However, no participant has a fixed obligation to pay the university interest on such deferred amount ... [emphasis added].

The implication is that since there is thus no obligation, tax principles concerning forgiveness of indebtedness or its payment by another are inapplicable. $\$ 8$

\section{Evaluation of the Revenue Ruling}

The Revenue Ruling applies to TPO principles which were developed in the context of individual loan transactions. In this section it will be argued that TPO is sufficiently distinguishable from such transactions to require a more fundamental analysis of TPO than that reflected in the Revenue Ruling.

Specifically, two alternate grounds will be proposed to challenge the validity of part of the tax deduction granted by the Ruling. The

43. Id. at 12. INT. REv. CODE of $1954 \$ 163(\mathrm{a})$ :

There shall be allowed as a deduction all interest paid or accrued within the taxable year on indebtedness.

44. Rev. Rul. 72-2, supra note 13, at 11-12, ciling Deputy v. dulont, 308 U.S. 488

(1910) and Old Colony R.R. Co. v. Comm'r, 284 U.S. 552 (1932).

45. Id., citing Kena, Inc. v. Comm'r, 44 B.T.A. 217 (1941).

46. See p. 1395 supra.

47. Rev. Rul. 72-2, supra note 13, at 12.

48. These principles are discussed at pp. $1403-04$ infra. 
first is that the penalty is not interest at all. And the second is that even if the penalty is interest, it is not interest on the debt of the borrower who pays it.

\section{A. The Penalty Payment as Insurance Premium}

The Ruling is correct in its assumption that a borrower and lender are ordinarily free to establish their own loan provisions and that interest need not be calculated as a percentage of principal. Payments may be geared to factors unrelated to the amount of the loan, and all resulting payments in excess of principal are deductible as "in. terest." The only requirement is that the "interest" must be paid for the use of borrowed funds. ${ }^{49}$

Thus, in a case cited in the Ruling, payments made under an agrecment to return a given percentage of profits derived from the investment of borrowed funds were held to be interest. ${ }^{50}$ And payments under an arrangement by which a man paid his wife 25 per cent of the profits of his business in exchange for a loan were deductible as interest, notwithstanding the fact that each annual payment approached or exceeded the principal amount. ${ }^{.1}$

The Yale TPO Plan computes repayment by a variety of devices. The size of each payment is proportional to income and the amount borrowed; the maximum total repayment is a function of the amount borrowed and a CIR; and the maximum repayment term is a specified number of years. All of these features are consistent with treating the penalty payments as interest.

But one other feature of the Yale Plan raises substantial questions about the characterization of penalty payments as interest. This is the variable Group Termination date, the date when the aggregate indebtedness of the entire Repayment Group is discharged. ${ }^{.2}$ The effect of this feature is that each borrower's obligation is partially determined by the payments of others, and thus ultimately (given the relationship of payments to income) by the size of his income relative to the average income of the Group. ${ }^{53}$

49. Old Colony R.R. Co. v. Comm'r, 284 U.S. 552 (1932).

50. Kena, Inc. v. Comm'r, 44 B.T.A. 217 (1941).

51. Dorzbach v. Comm'r, 195 F.2d 69 (3d Cir. 1952).

52. See pp. 1396-97 supra.

53. A borrower with average income for his Group has just repaid the amount of his own loan at the CIR when Group Termination occurs.

In computing the group average (mean), several adjustments must be made. First, because of the minimum payment, all incomes below $\$ 7250$ must be treated as being $\$ 7250$. Second, because of Early Termination, all incomes above 150 per cent of the 
Despite the form of the contract, which gives the appearance that the borrower makes payments solely in consideration of his own debt, it is questionable whether penalty payments necessitated by this last feature qualify as interest: i.e., that they are paid for the use of money. It seems more accurate to view these payments as made in exchange for the assumption by the entire Repayment Group of the risk that some borrowers will have incomes below the group average-providing, in effect, a form of income insurance. ${ }^{\mathrm{vJ}}$

The Yale literature on the plan in fact comments on this "income insurance" feature, assuming that it is one of the scheme's major attractions. ${ }^{50}$ And indeed, this feature does exhibit the two fundamental characteristics of insurance, risk shifting and distribution. ${ }^{57}$ The risk relative to the repayment of the loan of having an income below group average is shifted from the borrower. Such a shift would also occur if repayment were geared to income for a set term of years. In that case, the risk of a borrower's low income would be shifted to the lender. ${ }^{58}$ But the Yale Plan takes the further step of distributing that

average must be treated as being 150 per cent of the average. The cntire calculation is thus one of successive approximation. Finally, incomes must be veighted by the amounts borrowed.

54. The characterization of a transaction by the parties is not conclusire of its tax consequences. It is the duty of the Commissioner and the courts to look through the form of a transaction to determine its substance. See Deputy v. duPont, 308 US. 488, 497 (1940), in which no interest deduction was allowed because the "obligation" involved did not meet the statutory criteria of "indebtedness." A pajment cannot be characterized as interest if it is not "for the use of money." Llojd 5 . Comm'r, 1.51 F.d 643 (3d Cir.), cert. denied, 329 U.S. 717 (1946).

55. The IRS has consistently held that premiums paid for income maintenance are not deductible under $\$ 162$ or, apparently, under $\$ 212$ of the tax code. Rev. Rul. $\cdot \vec{j}$, 1959-1 Cum. Bunc. 12; Rev. Rul. 383, 1957-2 CuM. Bull. 44; I.T. 1918, III-1 Cus. Bun. 121 (1924). See also Andrews v. Comm'r, 29 CCH Tax Ct. Mrem. 93 (1970 No. 32). Furthermore, seen as insurance TPO involves a double deduction, since payments are deductible and receipts are nontaxable. See Treas. Reg. \$ 1.212-1(c) (1972); Rev. Rul. 383 supra. The same asymmetry results from an "interest" characterization. See p. 140J infra.

56. Tobin \& Pugash, supra note 34, at 2.

57. See Helvering v. LeGierse, 312 U.S. 531,539 (1911).

58. The same risk shifting from borrower to lender occurs cren in the typical loan case. A lender increases the interest rate he charges the individual borrower in light of the certainty that some borrowers will default. The lender himself bears the con. sequences in terms of his own overall rate of return if his estimate of defaults is too high or too low. Borrowers who do not default end up paying a greater interest rate than the average for borrowers as a whole, yet can clearly deduct the cintire armount paid as interest.

Insurance schemes have quite different risk-bearing consequences. Considering all the risks involved in collecting on a loan, a lender may decide that he does not wish to bear the risk of defaults arising from the deaths of borrowers. Rather than increasing the interest rate to all borrowers in the hope that the resulting extra incoine vili cover such defaults, he will charge all borrowers a lower interest rate, but also charge an insurance premium to purchase term insurance on their lives. The lender is then indifferent as to the frequency of borrower deaths, since the insurance pays him the outstanding indebtedness of deceased borrowers. The insurance company rather than the lender bears the risk of variations from the expected norm. The insurance premiums paid by the borrowers in such cases are not deductible. See note 55 supra.

The point of the discussion in the text is that the penalty paid by high income 
risk $^{59}$ over the entire Repayment Group, by measuring the obligation of each borrower by the payments made by all group members. Thus, a portion of the payments made by high-income borrowers is for risk distribution, not for the use of money, and should not qualify, for tax purposes, as interest.

To identify that portion which should not qualify as interest, it is necessary to begin with the Group Termination Account. As noted above, that account is equal to total principal plus aggregated interest minus payments by all group members. ${ }^{09}$ Despite disclaimers about repayment obligation, ${ }^{61}$ it is clear that the portion of the initial balance of that account attributable to an individual borrower can be easily calculated: it is the amount he individually borrowed plus interest at the CIR from the date of the loan. ${ }^{22}$ It is also clear that at Group Termination, each individual amount of principal, with interest at the contract rate, will have been paid in full, either by the individual borrower or by other members of his Group. The line that emerges in dividing interest payments from those properly attributed to risk distribution is the point at which an individual has repaid the principal he borrowed plus interest at the contract rate.

It should not be objected that these "insurance premiums" are paid by only a portion of the Group, or that they are made late rather than early. ${ }^{03}$ Risk shifting and distributing devices need not conform

borrowers under TPO is considerably more like the second situation than the first. The university is indifferent as to whether any particular borrowers (and up to a point whether borrowers as a whole) have incomes above or below predicted incomes. Varia. tions from expectations will affect the time of Group Termination, but whencver it does occur the university will have achieved its desired rate of return, i.e., the GlR. For the necessary qualification to this point in light of the possibility that Group Termination may not occur within thirty-five years, see note 59 infra.

59. The risk that Group Termination will not occur within 35 years will not be distributed over the Group, but will be directly borne by Yale. But all lenders may choose to bear some risks themselves, while avoiding other risks by charging bot* rowers insurance premiums. The fact, for example, that a lender charges extra interest for his risk of defaults for reasons other than death, does not affect the nondeductibility of the insurance premium he charges for the risk of defaults from deaths of borrowers.

In fact, Yale is not charging any fee for the risk it is bearing that Group Termination will not occur within 35 years. Such a fee, if included in the calculation of the CIR, would be decluctible as interest by all borrowers under the analysis put forth.

The actual risk to Yale is quite small. For example, the plan has lecwiy for incontes in constant dollars to average 30 per cent below expectations. Tobin \& 1'ugash, supra note 34, at 4. Group Termination was initially expected to occur within 26.28 ycars, id., but is now expected within 26 years. Yale Daily News, Mar. 3, 1972, at 1, col. 7 .

60. See p. 1397 supra.

61. Rev. Rul. 72-2, supra note 39, at 12. See p. 1399 supra.

62. See p. 1397 supra.

63. See, e.g., Comm'r v. Treganowan, $183 \mathrm{~F} .2 \mathrm{~d} 288$ (2d Cir. 1950), cert. denicd, 310 U.S. 853 (1950); Estate of Moyer v. Commissioner, 32 T.C. 515 (1959). These cascs char* acterized the payment of member death benefits by stock exchange organizations as insurance. The benefits were financed through initiation fees and through assessments levied upon surviving members at the time of a death. 
to the forms typical of the insurance industry. The mechanics of risk distribution can be expected to vary according to the risk involved. For those which produce loss that requires immediate lump-sum compensation, the device of the insurance premium to spread losses over time is desirable. And payment of premiums in advance creates a reservoir of funds that can be used when a loss occurs. Everyone who is insured pays the premium because those who will be injured are not identifiable at the time the fund must be created.

By contrast, there is no need for traditional premiums in the TPO Plan. The risk involved, a low income, is not a casualty risk, and its occurrence does not require an immediate, large payment. There is thus no need for advance pooling of funds. Spreading the loss over time is accomplished through continued payments by those who have not experienced the low income (against which they are insured), in proportion to the degree to which they have avoided that risk. In short, the mechanics of risk distribution in the Yale Plan appear well suited to the risk involved. ${ }^{\circ 4}$

The conclusion from this discussion is that all payments made by a borrower after he has paid enough to discharge his "personal" portion of the Group Termination Account, are payments made pursuant to a risk-sharing agreement. They are not paid for the use of money, and therefore despite the Revenue Ruling, should not be deductible as interest.

\section{B. The Penalty Payment as Non-Deductible Interest}

In order to qualify for an interest deduction, a taxpayer must be indebted and have an obligation to pay interest. ${ }^{05}$ When such interest is paid by another or forgiven, the taxpayer is not ordinarily entitled to take the deduction. ${ }^{60}$ However, if the taxpayer must include the amount so paid or forgiven as income $e^{\text {ot }}$ then he may deduct that amount as interest expense. ${ }^{.8}$ The net result, for a taxpayer who itemizes deductions, is that the income and the deduction cancel one

64. This arrangement is not unlike carly mutual insurance societies in Flanders, the members of which assessed themselves to indemnify a fellow member who suffered misfortune. See C. TrenerRy, The ORIGIN AND EARLY History of Isstrasce 251-59 (1920).

65. INT. REv. CODE of 1954 \$ 163(a). See, e.g., Chicago N. Shore \& Milwakice R.R. Co. v. Comm'r, 326 F.2d 860, 865-66 (7th Cir.), cerl. denied, 377 US. 961 (1961); D. Loveman \& Sons Export Corp. v. Comm'r, 34 T.C. 776 (1960), af/'d, 290 F.2d 732 (6th Cir. 1961), cert. denied, 369 U.S. 860 (1962).

66. Robbins Tire \& Rubber Co. v. Comm'r, 33 T.C. 275 (1969).

67. The general principle is that "[t]he discharge by a third person of an obligation ... is equivalent to receipt by the person [who was obligated]." Old Colony Trust Co. v. Comm'r, 279 U.S. 716, 729 (1929).

68. Cooledge v. Comm'r, 40 B.T.A. 1325, 1328 (1939). See also note 69 infra. 
another. If neither income nor deduction is reported, the taxpayer still receives an implicit interest deduction. ${ }^{\circ 0}$ The person who actually pays the taxpayer's interest in this situation is not entitled to a deduction, since the interest is not paid on his debt. ${ }^{70}$ If he werc allowed a deduction, the interest would be deducted twice, once by the indebted taxpayer and once by the person who paid it. ${ }^{71}$

As noted above, the Ruling held that

each participant has an individual obligation to pay the university his deferred amount. However, no participant has a fixed obligation to pay the university interest on such deferred amount ... ${ }^{2}$ [emphasis added].

So long as the individual makes his required payments, no payment made by any other participant is deemed to be interest on that individual's loan, and is not, therefore, taxable income to him. Similarly, the deductibility as interest of all payments made in excess of principal by any individual participant presents no difficulty under the rationale of the Ruling, as each individual is obligated to pay as much interest as the payment formula happens to produce. He is thus obligated to pay interest on indebtedness; he does so, and is entitled to at deduction. No double interest deduction arises under this analysis because everything a borrower pays is deemed to be on his own debt.

But the Ruling's analysis, developed in the context of an individual debt, fails in the unique situation created by a variable term contingent repayment plan. In the individual loan situation, the stated interest rate represents the total return to the lender from the money loaned to a particular borrower. Even where payments are calculated according to a percentage of profits ${ }^{i 3}$ the size of the payments still

69. Cf. Dean v. Comm'r, 35 T.C. 1083 (1961) (interest free loan from corporation to sole owner, not taxable income to owner because interest would be deductible anyway). Most cases requiring that forgiven interest be recorded as income are based on the need to offset an earlier interest deduction taken by an accrual basis taxpayer when his interest obligation is later forgiven. See, e.g., Helvering v. Jane Holding Corp., 109 F.2d 933 (8th Cir.), cert. denied, 310 U.S. 653 (1940). Such cancellation of a prior cxplicit deduction leaves intact the implicit interest deduction suggested in the text.

70. In Simon v. Comm'r, 36 B.T.A. 184 (1937), it is held that

the principal indebtedness on the note was solely that of [another], and the interest which petitioner undertook to pay was not interest on his indebtedness, and prop. erly speaking may not as to him be called interest at all.

Id. at 185-86. No deduction is allowed even where such payments are required by contract. Eskimo Pie Corp., 4 T.C. 669 (1915), aff'd, 153 F.2d 301 (3d Cir. 1916).

71. Such duplication of the interest deduction would be against the policy of the tax code. See Cooledge v. Comm'r, 40 B.T.A. 1325, 1328 (1939). Cf. 'Treas. Keg. \$ 1.161.1 (1958): "Double deductions are not permitted." But see World Publishing Co. v. Comm'r, 299 F.2d 614, 622-23 (8th Cir. 1962).

72. Rev. Rul. 72-2, supra note 13 , at 12 .

73. See p. 1400 supra. 
determines the lender's return on that principal. By contrast, in a variable term contingent repayment situation, the payments made by each borrower do not determine the rate of return to the lender from the individual loan. Rather, that return is calculated by application of a given interest rate to the principal borrowed. is The contingent payments made by each borrower, far from defining the return that the lender will realize, are merely applied against a predetermined return. And if the payments made by one participant are not enough to discharge his principal plus the stated interest rate, someone else is required to pay the deficiency. Therefore, the simple fact that no participant has a "fixed obligation to pay the university interest" is seems unpersuasive in the present absence of the implicit second condition, namely that the university is not guaranteed any given return on the money it has loaned any given participant.

Variable term, quasi-group debts thus are not necessarily amenable to analysis developed for individual debts. In particular, it is necessary under the Yale Plan to determine not merely the amount each individual pays, but also the source of the obligation which his payment discharges. Once he has paid enough to discharge the obligation generated by his principal, further payments are against interest generated by the debts of others. Those others receive an implicit interest deduction, as they do not report as income the difference between the interest actually generated by their principal and the amount they pay. Thus deduction of such amounts by the persons making the payments is in effect a double deduction of that interest, impermissible under the principles noted above.

\section{The Interest Deduction as a Subsidy to Education: Policy Considerations}

The ideal device to achieve equal educational opportunity would be one which precisely identified a student's ability, both present and future, to pay for educational services, and then supplied the deficiency-tailoring financial assistance to the need of the student. This could involve the state's paying tuition or living expenses, or, conceivably, providing support for persons dependent on the prospective student.

Even in a world of ample public resources, the calculation of a

74. See p. 1397 supra.

75. Rev. Rul. 72-2, supra note 13, at 12. See p. 1404 supra. 
student's ability to pay should include the amount he could be cxpected to borrow. But in the world of limited public funds, educitional loans must be the primary vehicle for pursuing equal educational opportunity. ${ }^{76}$ It is critically important, then, to construct a loan system that will: (1) maximize the amount students can borrow, (2) encourage students to borrow that maximum, if necessary to finance their education, and (3) do this by the most efficient use of the limited government subsidy.

In the remainder of this Note it is argued that by such criteria a contingent repayment system is superior to conventional education loans. However, it will be suggested that the Revenue Ruling may foreclose desirable experimentation to determine the most efficient use of government subsidies in such plans.

The necessity of repayment within a comparatively short term imposes an upper limit on the amount of conventional educational debt a student can bear. Moreover, since the repayment years normally coincide with a former student's years of lowest income, the maximum sustainable payments (and thus, the maximum feasible loan) are held at relatively low levels. ${ }^{7}$ Finally, the fixed payments required by conventional loans, coupled with students' inevitable uncertainty about their future incomes, ${ }^{78}$ will tend to decrease their willingness to borrow. The specter of high fixed payments along with the posa sibility of relatively low income seems unlikely to encourage borrowa ing at the optimal level. ${ }^{70}$

Contingent repayment plans tie repayment to income rather than to the amount borrowed and extend payments over a longer term, producing two benefits. First, they increase the amount of educational debt that a student is able to discharge. The extended term makes repayment less burdensome. And since payments are concentrated in the latter portion of the borrower's earning career, the limitation

76. The cost of even a modest grant program to institutions, which would provide them up to $\$ 1000$ per needy student would be about $\$ 5$ billion per ycar. 1970 Education Hearings, supra note 2, at 553-54. This should be compared with the \$100 million that the government is likely to spend this year for institutional grants. N.Y. Times, Mar. 2, 1972, at 45 , col. 7 . See note 7 supra.

77. Long term conventional loans are, of course, possible, and would somewhat reduce the urgency of this objection. But even a 30-year conventional loan with ilterest at seven per cent subsidized during four years of college would require annual payments of $\$ 85$ per year per $\$ 1000$ borrowed. Under TPO, such payments would not be recuired until income rose above $\$ 20,000$.

78. This uncertainty is well-founded, given the large variation of income annong college graduates. Some 20 to 35 per cent of the graduates will have incomes below the average for all income earners in their region. 1970 Education Hearings, supra note 2 , pt. 1 , at 444 .

79. See Daniere, The Benefits and Costs of Alternative Federal Programs of Financial Aid to College Students, in Economics Compendum, supra note 4, at 556, 576.81. 
imposed by initially low income is removed. Second, they should increase the amount a student is willing to borrow. As payments are determined by income, the chance of having a low income should no longer be a deterrent to borrowing. To the extent that a student bases borrowing decisions on a cost-benefit analysis, contingent repayment plans should further encourage a willingness to borrow by directly relating the cost of the loan to his overall economic benefit from the education purchased, thus reducing the risk that educational costs will exceed benefits.

One possible drawback of contingent repayment plans-among those most feared-is that only those expecting low incomes will participate and that the sponsor of the plan will have to absorb considerable losses as a result. Concern about this possibility is acutely evident even when the federal government is asked to participate. ${ }^{80}$ Limited federal funds would quickly be exhausted unless the deficit created by lowincome borrowers is offset by a surplus generated by those with high incomes.

But this fear of "adverse selection" may be groundless. It is by no means clear that many students are so certain of having high incomes that they will not insure against the possibility of a low one through participation in the plan. Even if there are many students so optimistic, it is far from certain that they will ultimately have the high incomes.

Unfortunately, as a result of the Revenue Ruling, it will be more difficult to discover whether the adverse selection danger really exists: the Ruling grants a tax deduction that may not, in fact, be necessary to induce high-income expectants to participate in contingent repayment plans. The experimental opportunity thus foreclosed by the Ruling becomes clear when one considers the subsidy implications of other possible contingent repayment arrangements. ${ }^{81}$

80. See note 2 supra.

81. Contingent repayment plans of other universities differ from Yale's TPO in a number of respects. None of these other plans requires borrowers with high incomes to repay more than they would have to pay at commercial loan rates; i.e., all are subsidized. See pp. 1394-95 supra.

The comparison with the Duke University plan, in effect in 1971-72, is particularly striking. See Duke University, Duke University Deferred Tuition Plan, May 31. 1971. First, undergraduate borrowers must repay .36 per cent of their adjusted gross incomic per $\$ 1000$ borrowed for a fixed thirty years, with a minimum repayment similar to Yale's. Id. S\$ IV A, V, app. A. There is thus no concept of Group Terninntion. Students pay ten per cent less each year than under the Yale Plan. They give up the chance to stop paying within thirty years even if they have relatively low incones, a possibility under the Yale Plan occurring if Group Termimation occurs within 30 years. Likewise, Duke borrowers need not worry about Group Termination not occurring within 30 years.

Second, borrowers in different schools of Duke repay at different rates. For cxample, law students have among their options the choices of paying .40 per cent for twenty years, or .72 per cent for ten years. Id. app. B. Medical students imay choose 30 per 
There are a number of ways to make a tuition postponement plan largely self-supporting. If the plan is designed with a fixed termination date, the designers must project the average income level of the participants and impose a repayment rate which will cause the aggregate debt to be redeemed by the termination date. If it is essential that the plan be self-supporting, there is considerable pressure on the designers to build in comfortable margins in the repayment rate or period, or both, to insure that the plan will not lose money. This problem is particularly acute during the initial period of operation. The difficulty is that such margins simultaneously decrease the utility of the plan to those expecting or fearing low incomes and reduce its attractiveness to those who anticipate relatively high ones. Such actions may cause adverse selection to become a self-fulfilling prophecy. ${ }^{\text {\& }}$

cent for ten years or .75 per cent for five years. Id. app. C. It is clear that medical stil. dents are most favored, law students are in the middle, and undergraduates are lcast favored, as compared with the Yale Plan.

Third, regardless of his income no Duke borrower pays more than the cquivalent of repaying his original loan at a fixed interest rate of cight per cent. Reaching that level-by anmual payments or by buying out-ends all further obligation. Id. \$ IX. No borrower under the Duke plan, therefore, pays more than does the average borrower under the Yale Plan. Duke simply bears the cost itsclf, rather than placing the burden on borrowers with high incomes.

Harvard University is taking still another approach with a plan beginning this ycar. Harvard University Student Loan Office, Background and Basis of the new Harvard Loan Program, undated (mimeo.). Student loans will be made so as to meet the require. ments for the federal guarantec against defaults and the federal interest subsidy. I ${ }^{\text {. }}$ at 1. No borrower can be required to pay more than a seven per cent interest rate, maximum term is ten years, and annual payments must total $\$ 360$. But therc is no federal requirement that the loan repayment schedule consist of level payments: Harvard's minimum repayment schedule for a total loan obligation of $\$ 4000$ (the normal under. graduate maximum) will require payments of $\$ 360$ the first year, gradually rising to $\$ 828$ in the tenth and final ycar. $I d$. at 3.

No Harvard borrower will be required in any year to make payments in an amount greater than six per cent of his income for that year regardless of the amount borrowed. If the repayment schedule would require such payments in a given year, Harvard will offer to substitute its own one-year renewable notes (at seven per cent interest) for the excess amount over six per cent of income (as if the student had borrowed money from an outside source to repay his federal guaranteed loan). In any year when Harvard's own notes are outstanding, the borrower must pay the full six per cent of income, payments going first to meet the federal loan obligation as far as possible, and any excess going to meet the Harvard obligation. At the end of ten years, no federal loall obligation will be outstanding, but the borrower might have Harvard notes outstanding. Borrowers with outstanding notes must pay six per cent of income for at most three years, or until the notes are fully paid. If notes are still outstanding after threc years (13 years after repayments began), Harvard will offer to forgive the balance, at its own cxpense. Id. at $4-5$.

Similar to the Harvard system is the loan plan recently enacted in Now York Statc, expected to begin operation in September 1973. Any student attending a New York institution will be able to borrow up to $\$ 2500$ per academic year directly from his own college. The state mortgage agency will immediately buy the note at full valuc from the college, and the student will make payments during the ten-year repayment period directly to the state. The interest rate will not exceed seven per cent, and stitdents with low incomes could have repayments suspended. Act of May 8, 1972, ch. 231, [1972] N.Y. Session Laws.

82. Overall future income levels of borrowers are a significant factor in detcrmining the repayment terms that are required, despite calculations to the contrary in Shell, Notes on the Educational Opportunity Bank, 23 NA't' TAx J. 214 (1970). For cxample, 
By contrast, a plan becomes much more precise if it incorporates, as does the Yale Plan, a variable payment term. In this case, the precision of initial projections is less critical, because errors are corrected automatically by the variable termination date. There is no need to increase the repayment rate to hedge against unexpected adverse selection. As a result, the rate stays lower, making it less likely adverse selection will in fact occur. At the same time it produces a plan more useful to those who expect low incomes.

The variable term plan also seems to be more efficient from the standpoint of subsidies to education. In a fixed-term plan, an interest deduction must be granted for all payments beyond principal, under the general tax rules discussed above. This subsidy is locked into such a plan regardless of its effectiveness in promoting equal access to education. In the case of variable term plans, as has been argued, no interest deduction should be given for the high-income "penalty" payments. This would allow the government to tailor its subsidies to most efficiently promote educational equality. ${ }^{83}$ Such a plan should be operated, at least initially, without a tax subsidy, in order to determine the truth of the theory of adverse selection. For the reasons given above, ${ }^{84}$ and because an interest deduction is valid for payments made prior to the penalty, contingent repayment plans of this type may not need an additional tax subsidy to attract high-income borrowers. If that is the case, the interest deduction granted by the Revenue Ruling, when considered as a subsidy to promote access to education, is essentially wasted.

a 30 per cent underestimate of incomes of TPO borrowers (the same percentage in effect used by Shell) would delay Group Termination by as much as eight years. See note 59 supra. Note that the Duke plan requires significantly different repajment mates from student groups with differing income expectations. See notc 81 supra.

83. To understand the magnitude of the subsidy involved in allowing deduction of the penalty, consider the following example provided by Yale Unirersity, The Yale Tuition Postponement Option 1972-73, undated. This example postulates a freshman participant whose income (projected as the seventieth percentile) rises through the range of $\$ 10,000-\$ 54,000$, in constant 1972 dollars. A CIR of seven per cent is assumed. For each $\$ 100$ he borrows he will repay $\$ 597$ by the time he reaches Early Termination after 24 years. The $\$ 497$ representing "interest" will producc a tax saving of $\$ 200$.

It is necessary to go beyond the Yale figures to deternine how unth of that tax saving is attributable to deduction of penalty payments. The following figures result.

$\begin{array}{lcc} & \text { Amount of } & \text { Tax } \\ & \text { "Interest" Paid } & \text { Savings } \\ \text { Payments on "own debt" } & \$ 197 & \$ 69 \\ \text { "Penalty" after repaying "own debt" } & \$ 300 & \$ 132\end{array}$

These savings on the penalty deductions, when discounted at an cstimated CIR of seven per cent, yield a present value of about \$23, for each \$100 borrowed. This is roughly equivalent to the subsidy granted to students under the Federal Guaranteed Loan Program. See note 5 supra. The size of the subsidy will vany from person to person, but everyone above the fiftieth percentile will reccive some subsidy.

84. See pp. 1406-07 supra. 
Should experimentation indicate that adverse selection is a scrious danger, a deliberate decision could be made to subsidize the plan in the most efficient manner. Depending on the degree of adverse selection and the experimentally determined success of tax incentives in attracting high-income borrowers, direct absorption of the net losses of such plans may well provide more assistance to low-income student borrowers than the tax deduction will prove an incentive to highincome participation. Or the experiments might indicate that some entirely different form of subsidy is most beneficial.

Whatever the result, the subsidy would then have been chosen for its effectiveness, not haphazardly bestowed by the tax authorities. But the Ruling unfortunately appears to have foreclosed the possibility of desirable experimentation in this area by eliminating the possibility of nondeductible penalties.

\section{Conclusion}

It is doubtful under the Internal Revenue Code whether all nonprincipal payments made under certain contingent repayment plans should be deductible. A critical reexamination of the merits of the relevant Revenue Ruling should be undertaken. Congress, in any event, should not permit this Ruling-or any other-to foreclose experimentation as to the most efficient means of subsidizing contingent repayment plans. Equal educational opportunity is a goal well worth the cost of experimentation. As a means to that goal, contingent repayment plans are well worth pursuing. 